\title{
Rhizosphere Bacterial Composition of the Sugar Beet Using SDS-PAGE Methodology
}

\author{
Milad Aeini' ${ }^{1}$, Gholam Khodakaramian ${ }^{1}$. \\ ${ }^{1}$ Bu Ali Sina University - Plant Protection Hamedan, Iran.
}

\begin{abstract}
The rhizosphere zone has been defined as the volume of soil directly influenced by the presence of living plant roots or soil compartment influenced by the root. During the growing season of 2014, the rhizobacteria of 23 sugar beet plants sampled from 12 sites in the west and north west of Iran were inventoried. Using a cultivation-dependent approach, a total of 217 bacteria were isolated from the rhizosphere. The bacterial isolates were tentatively grouped and documented based on polyacrylamide gel electrophoresis of whole-cell proteins and were found to represent 43 different protein electrotypes. The majority of the fingerprint types were found only on a single occasion. Fifty-nine percent of the strains belonged to the five bacterial species and identified as Stenotrophomonas maltophilia, Pseudomonas fluorescens, Pseudomonas aeruginosa, Stenotrophomonas rhizophila and Serratia marcescens. Minor occurring fingerprint types were identified as Flavobacterium spp, Erwinia spp, Acetobacter spp, Agrobacterium spp, Enterobacter spp, Aeromonas spp and Bacillus spp.
\end{abstract}

Key words: Rhizosphere, Sugar beet, SDS-PAGE, Protein fingerprint.

*Author for correspondence: khodakaramian@yahoo.com 


\section{INTRODUCTION}

The rhizosphere is defined as narrow zone of soil influenced by plant roots which is inhabited by a unique population of microorganisms. In comparison to the root-free soil, the rhizosphere forms a nutrient-rich niche for microorganisms as a result of exudation of organic compounds (1). Additionally, this microenvironment is described as microbial hot-spot where various interactions between organisms, beneficial as well as pathogenic, take place (2). Bacteria are the most numerous inhabitants of the rhizosphere, with population numbers typically ranging between 106-109 cfu g-1 of rhizosphere soil. The number of bacteria associated with plant roots (per gram of soil) is 10- to 100- fold greater than the bacterial density associated with bulk soil (3). Beneficial free-living rhizosphere bacteria are usually referred as plant growth-promoting rhizobacteria (PGPR). PGPR are specific strains of bacteria in the rhizosphere that enhance seed germination and plant growth (4). Several attempts have been made to show the role of beneficial bacteria in increasing the growth and yield of various crops such as rice (5), wheat (6) and sugar beet (7) many others have been reported in the past. Naturally, rhizobacteria is among the known useful microbes that directly (through secretion of various phytohormones) or indirectly (by competitive inhibition of pathogens) assist plant growth (8). Native bacteria isolated from a specific plant rhizosphere may contain highly efficient genotypes to promote plant growth and perform this function better than exotic strains (9). As can be expected, investigations of the native bacterial population, their characterization and identification are essential for understanding the distribution and diversity of indigenous bacteria (10). Therefore, standard culture techniques to characterize microbial ecology involve isolation and characterization of microorganisms using commercial growth media such as Luria-Bertani medium, Nutrient Agar, and Tryptic Soy Agar (11). Consequently, studies based on the characterization of culturable rhizosphere bacteria, have recommended that plants can have specific effects on microbial communities (12). In addition, polyacrylamide gel electrophoresis of bacterial proteins have been used as an efficient technique for the classification of microorganisms, based on phenotypical characteristics expressed by their protein profiles. Bacterial groupings based on electrophoretic profile correlate very well with the results obtained by the DNA hybridization $(13,14)$. There are indications that some rhizobacterial strains show strong host-plant selectivity and colonize a single plant species or variety. Under these circumstances, specific microorganisms are enriched from the surrounding environment as well, e.g., attracted by root exudates containing carbohydrates, proteins, and vitamins (15). As a result of these processes, each plant harbors to a certain degree specific microbes $(16,17)$. This specificity was also revealed for the plant-associated microbial at cultivar level, e.g. for rice (18). Thus, the objectives of this study are to: 1) isolate naturally occurring which colonize sugar beet rhizosphere, 2) use SDSpolyacrylamide gel electrophoresis (SDS-PAGE) for grouping the isolates, and 3) identify major occurring bacteria on the basis of the biochemical tests as well as by $16 S$ rRNA gene sequence analysis.

\section{MATERIAL AND METHODS}

\section{Sampling}

The samples were taken from a total of 7 regions (Malayer, Hamedan, Eslamabad-e Gharb, Kermanshah, Mahidasht, Miandoab and Shahin Dezh). Convenience sampling coupled with a plant health scale that was based on the physical appearance of the plants was used in subsistence farming fields. Plants were ranked on three 
levels: $0=$ wilted/pale yellow leaves, $1=$ wilted/green leaves and $2=$ not wilted/green leaves. Only those with a healthy appearance level 2 were selected. A systematic sampling method, where samples were selected along a 30-50 m transect line at 10$\mathrm{m}$ intervals, was used to select plants from pristine areas. Samples were collected by digging up a whole plant, with adherent soil into plastic bags, transported to the laboratory within $12 \mathrm{~h}$, then stored at $4^{\circ} \mathrm{C}$. The isolation of rhizospheric bacteria was performed a day after.

\section{Isolation of Bacteria}

For the isolation of rhizospheric bacteria, adhering soil was carefully brushed off from the roots to remove excess soil. Hairy Roots were then shaken for $10 \mathrm{~min}$ a mechanical gyratory shaker in $100 \mathrm{ml}$ of sterile phosphate buffer $(\mathrm{PB})$ containing: peptone, $1.0 \mathrm{~g}$; K2HPO4, 1.21g; KH2PO4, $0.34 \mathrm{~g}$, per liter. The bacteria were isolated by serially diluting the rhizosphere soil and spreading $100 \mu \mathrm{l}$ of the diluted sample onto nutrient agar (Difco Laboratories, Detroit, Mich.), containing 10\% Trypticase soy broth (BBL Microbiology Systems, Cockeysville, Md.) plus 2\% agar (TSBA). All the media plates were supplemented with benomyl 20ppm to avoid the growth of fungi. The plates were then incubated at $30^{\circ} \mathrm{C}$ for growth of bacteria. From each medium, one colony per colony type was isolated and purified on nutrient agar. All the procedures were carried out under sterile conditions. The bacterial colonies were isolated individually on nutrient agar plates and stored in slants for further studies.

\section{Isolation of Total Cell Protein}

One loopful of $48 \mathrm{~h}$ grown fresh culture was inoculated into $50 \mathrm{ml} \mathrm{KB}$ broth and incubated with shaking $(180 \mathrm{rpm})$ for $48 \mathrm{~h}$ at $28 \pm 2{ }^{\circ} \mathrm{C}$. The bacterial cells were harvested in their logarithmic growth phase by centrifugation at $6000 \mathrm{rpm}$ for 10 min. The harvested cells were washed twice in cold Tris-buffer (3.3 mM, pH 7.4), lysed by suspending in lysis buffer $(10 \mathrm{mM}$ Tris- $\mathrm{HCl}, \mathrm{pH} 7.4,0.75 \mathrm{M}$ sucrose, 100 $\mu \mathrm{g} / \mathrm{ml}$ lysozyme) and incubated on ice for $10 \mathrm{~min}$ and vortexed. The resulting cell suspension was incubated for $30 \mathrm{~min}$ at $4{ }^{\circ} \mathrm{C}$ before centrifugation at $10000 \mathrm{rpm}$ for 20 min. The supernatant was used as the total cell protein source for electrophoresis (19).

\section{Protein Analysis Through SDS-PAGE}

SDS-PAGE analysis of the proteins was carried out in polyacrylamide slab gels consisting of $4 \%$ stacking gel and $12 \%$ separating gel using the Hoefer minielectrophoresis system (Amersham Biosciences, Sweden).

Samples with an equal amount of protein $(50 \mu \mathrm{g})$ were dissolved in sample buffer and denatured by boiling for 4 min before loading onto the gel. From each sample, $30 \mu \mathrm{l}$ was loaded on a discontinuous polyacrylamide gel (12\% acrylamide, $0.09 \%$ SDS) similar to the one described by Laemmli (20). Electrophoresis was carried out at a constant voltage of $65 \mathrm{~V}$ for approximately $2 \mathrm{~h}$. Gels were stained overnight in a solution containing $40 \%$ methanol (v/v) and 10\% acetic acid (v/v) and $1 \%$ Coomassie brilliant blue and destained in a solution containing $40 \%$ methanol $(\mathrm{v} / \mathrm{v})$ and $10 \%$ acetic acid (v/v). Standardization of gel length was obtained by photography. The reproducibility of the SDS-PAGE technique was estimated by including duplicate runs of a single protein extract on separate gels. The photographs of the protein patterns were compared visually.

\section{Biochemical Tests and $16 \mathrm{~S} r \mathrm{RNA}$ Gene Amplification}

One isolate of each fingerprint type was further characterized by Gram's reaction, colony characteristics on nutrient agar, oxidase, OF-test and fluorescence on King's 
medium B. Gram-positive isolates were characterized by cell morphology and motility. A series of biochemical tests were conducted to characterize

the isolated bacteria using the criteria of Bergey's Manual of Systematic Bacteriology (21). The $16 S$ rRNA gene was amplified using fD1 (5'CCGAATTCGTCGACAACAGAGTTTGATCCTGGCTCAG-3') and rD1 (5' CCCGGGATCCAAGCTTAAGGAGGTGATCCAGCC-3) primers (22). These primers are designed to yield nearly full-length $16 S r R N A$ gene from most bacteria. Each vial contained $50 \mu \mathrm{l}$ of reaction mixture containing $32.25 \mu \mathrm{l}$ nano-pure water, 5 $\mu \mathrm{l}$ of $1 \mathrm{X}$ PCR buffer, $6 \mu \mathrm{l}$ of $25 \mathrm{mM} \mathrm{MgCl}$, and $0.5 \mu \mathrm{l}$ of $1 \mathrm{U}$ Taq polymerase, $1 \mu \mathrm{l}$ of $2 \mathrm{mM}$ dNTPs, $2 \mu \mathrm{l}$ of each primer (fD1, rD1, $10 \mathrm{pmol} / \mu \mathrm{l}$ ) and $1 \mu \mathrm{l}$ template DNA, respectively. PCR conditions were as follows: Initial denaturation temperature at $94^{\circ} \mathrm{C}$ for $2 \mathrm{~min}$ and 30 cycles, including a denaturation step at $95^{\circ} \mathrm{C}$ for $1 \mathrm{~min}$, an annealing step at $61^{\circ} \mathrm{C}$ for $1 \mathrm{~min}$, an extension step at $72^{\circ} \mathrm{C}$ for $2 \mathrm{~min}$ and a final extension step at $72^{\circ} \mathrm{C}$ for 6 min. Finally, the PCR product was analyzed on $1 \%$ agarose gel, stained with ethidium bromide, and visualized under UV illumination and sequencing of the $16 \mathrm{~S}$ rRNA gene was performed by Bioneer Company, South Korea.

\section{Phylogenetic Analysis}

The obtained $16 S$ rRNA gene sequences were compared with the submitted sequences in the GenBank using Using the NCBI BLASTn. Sequences obtained were blasted with the GenBank database (http://www.ncbi.nlm.nih.gov/) 16S Ribosomal RNA Sequences (Bacteria and Archaea) for species assignment. The phylogenetic tree and molecular analysis were carried out using the Molecular Evolutionary Genetics Analysis (MEGA7) software. Using the NCBI BLASTn, we were able to compare the gene sequences with others in the GenBank database. Multiple sequence alignments were performed by ClustalX and phylogeny was determined by the neighbor-joining method. The sequences submitted to the GenBank and assigned the accession number.

\section{RESULTS}

\section{Isolation of Bacteria and SDS-PAGE Grouping}

A total of 217 bacteria were isolated from the rhizosphere of 23 sugar beet plants samples in seven different regions in the west and north west of Iran (Fig 1, Table 1). Only quantitatively important colony types were isolated. The isolates were tentatively grouped and documented based on polyacrylamide gel electrophoresis of total cell proteins. According to a definition provided by Lambert et al (1987), a protein fingerprint type or protein electrotype is a set of similar protein profiles obtained under standardized conditions (23). Thus, all electrotypes were numbered and designated SBR. All electrotypes showed characteristic and reproducible patterns. We were able to detect identical strains isolated from different plants of the same or different regions. 
Rhizosphere bacterial of the sugar beet

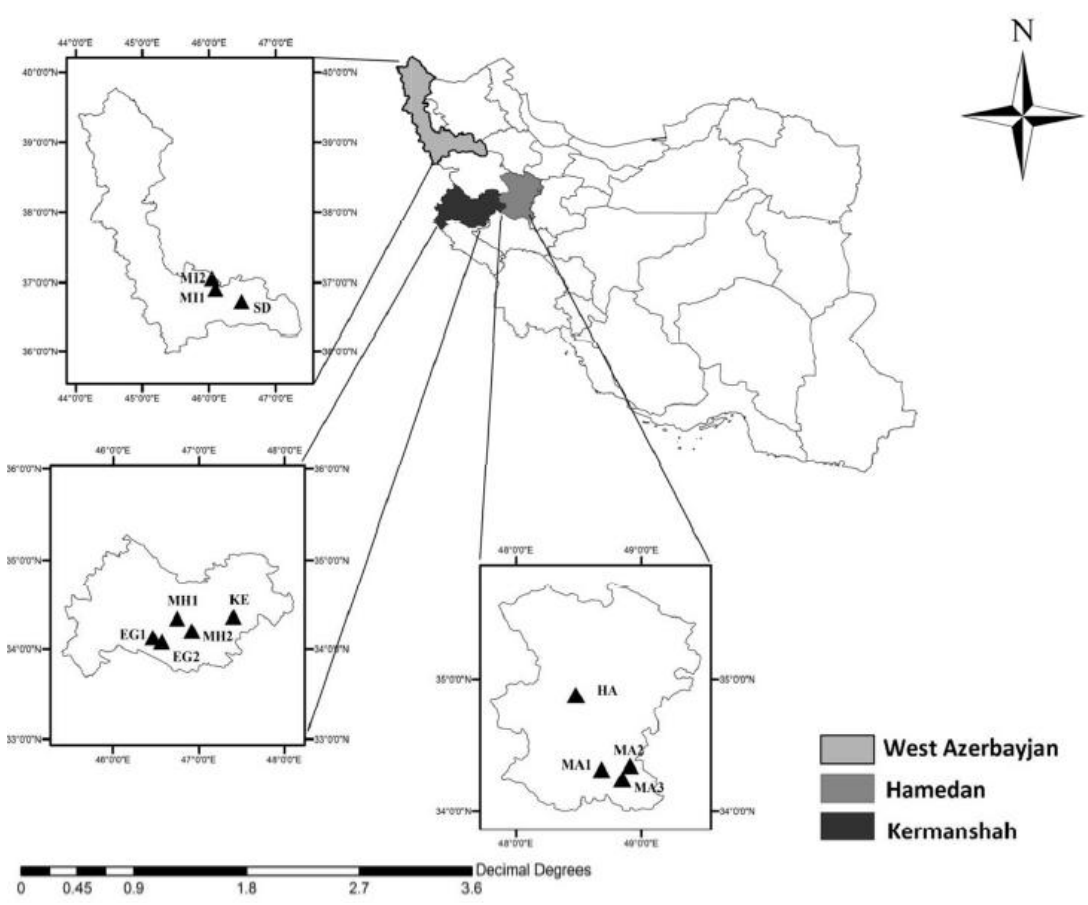

Figure 1- Map pf Iran showing sampling regions.

Table 1. Overview of sampling.

\begin{tabular}{|c|c|c|c|c|c|}
\hline $\begin{array}{l}\text { Locality of } \\
\text { collection }\end{array}$ & $\begin{array}{l}\text { Sampling } \\
\text { code }\end{array}$ & Varieties & $\begin{array}{l}\text { Number of } \\
\text { plants } \\
\text { analyzed }\end{array}$ & $\begin{array}{c}\text { Number of } \\
\text { isolates }\end{array}$ & $\begin{array}{l}\text { Frequency of } \\
\text { electrotypes }\end{array}$ \\
\hline Kermanshah & KE & Muraille & 2 & 35 & 21 \\
\hline Mahidasht & $\begin{array}{l}\text { MH1 } \\
\text { MH2 }\end{array}$ & Rusta & 4 & 30 & 26 \\
\hline $\begin{array}{l}\text { Eslamabad-e } \\
\text { Gharb }\end{array}$ & $\begin{array}{l}\text { EG1 } \\
\text { EG2 }\end{array}$ & Rusta & 4 & 27 & 17 \\
\hline Hamedan & HA & Ekbatan & 2 & 38 & 28 \\
\hline Malayer & $\begin{array}{l}\text { MA1 } \\
\text { MA2 } \\
\text { MA3 }\end{array}$ & Poma & 5 & 40 & 29 \\
\hline Shahin Dezh & SD & Dorothea & 2 & 20 & 8 \\
\hline Miandoab & $\begin{array}{l}\text { MI1 } \\
\text { MI2 }\end{array}$ & Dorothea & 4 & 27 & 16 \\
\hline Total: 7 & 12 & 5 & 23 & 217 & \\
\hline
\end{tabular}

Distribution and Identification of the Protein Fingerprint Types

The rhizosphere isolates obtained from sugar beet showed 43 different protein electrotypes. The majority of electrotypes (38 of 43) were isolated on a single occasion and grouped as minor fingerprint types (Table 2).

The gram-negative minor fingerprint types were identified as Flavobacterium spp, Erwinia spp, Acetobacter spp, Agrobacterium spp, Enterobacter spp and Aeromonas spp respectively. Only one genus of gram-positive bacteria was detected as Bacillus sp which comprises six different fingerprint types (13\% of fingerprint types). Five fingerprint types designated SBR (SBR01, SBR05, SBR10, SBR13 and SBR 21) were present in relatively large quantities during the sampling period (Table 3) (Fig 2). Together, they comprised 59\% of the isolates (11\% of the fingerprint types). Five main representative electrotypes have been chosen for closer biochemical and molecular studies (Table 4). Interestingly, the fingerprint type SBR01 (31 isolates), 
identified as Stenotrophomonas maltophilia, was constantly recovered from all plants. Fingerprint type SBR10 (27 isolates) was found on 19 roots from six sampling regions and identified as Pseudomonas fluorescens. Fingerprint type SBR05 (25 isolates) was obtained from 18 roots from different sampling regions. This fingerprint type was characterized as Stenotrophomonas rhizophila. Fingerprint type SBR21 was found on 16 roots (23 isolates) from different sampling regions and was characterized as Pseudomonas aeruginosa. The last major fingerprint type (SBR13) was characterized as Serratia marcescens and was found on 14 roots. The remaining electrotypes were found on more than one plant and only 5 of them on 14 to 23 plants. Biochemical and molecular analysis of the representative isolates are listed in table 4. PCR amplification of $16 \mathrm{~S} r R N A$ gene yielded DNA fragments of single bands at 1,500 base pairs for each representative strains (Fig 3). To detect any phylogenetic relationship with representative strains, the $16 S$ rRNA gene sequences of the isolated bacterial strains were determined and compared with the available $16 S$ rRNA gene sequences. The $16 S$ rRNA gene sequences of representative strains showed high homology with those strains $(98-100 \%)$ (Fig 4). The $16 S$ rRNA gene sequences have been deposited in the GenBank database and assigned accession numbers KX018308- KX018312.
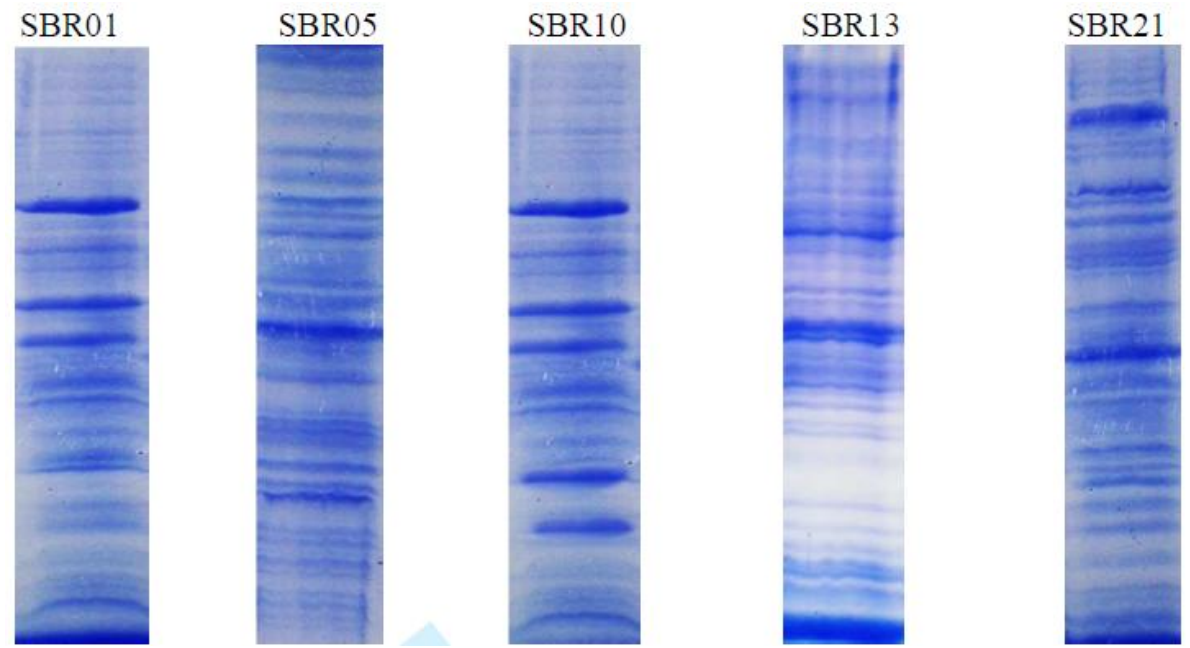

Figure 2- Representative protein electrotypes of the five major fingerprint types.

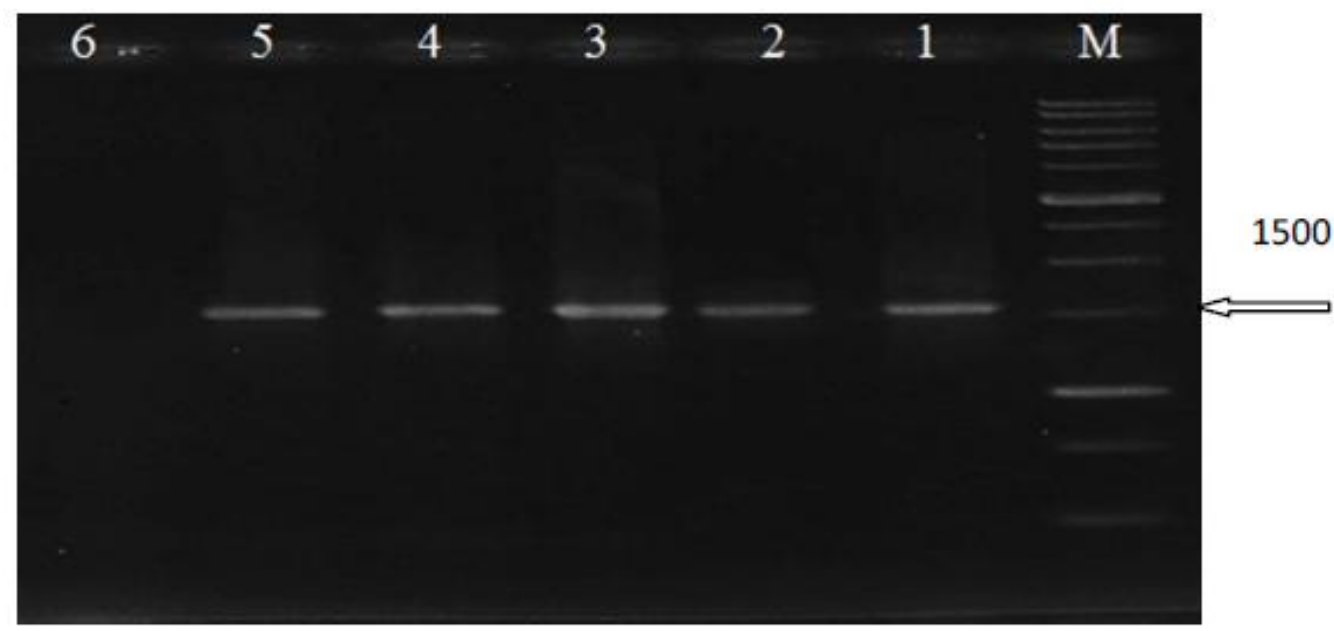

Figure 3- Agarose gel electrophoresis of PCR-products of representative strains with primers rD1 and fD1. M: 1 KB ladder, (1) SBR01; (2) SBR05; (3) SBR10; (4) SBR13; (5) SBR21 and (6) negative control. 
Rhizosphere bacterial of the sugar beet

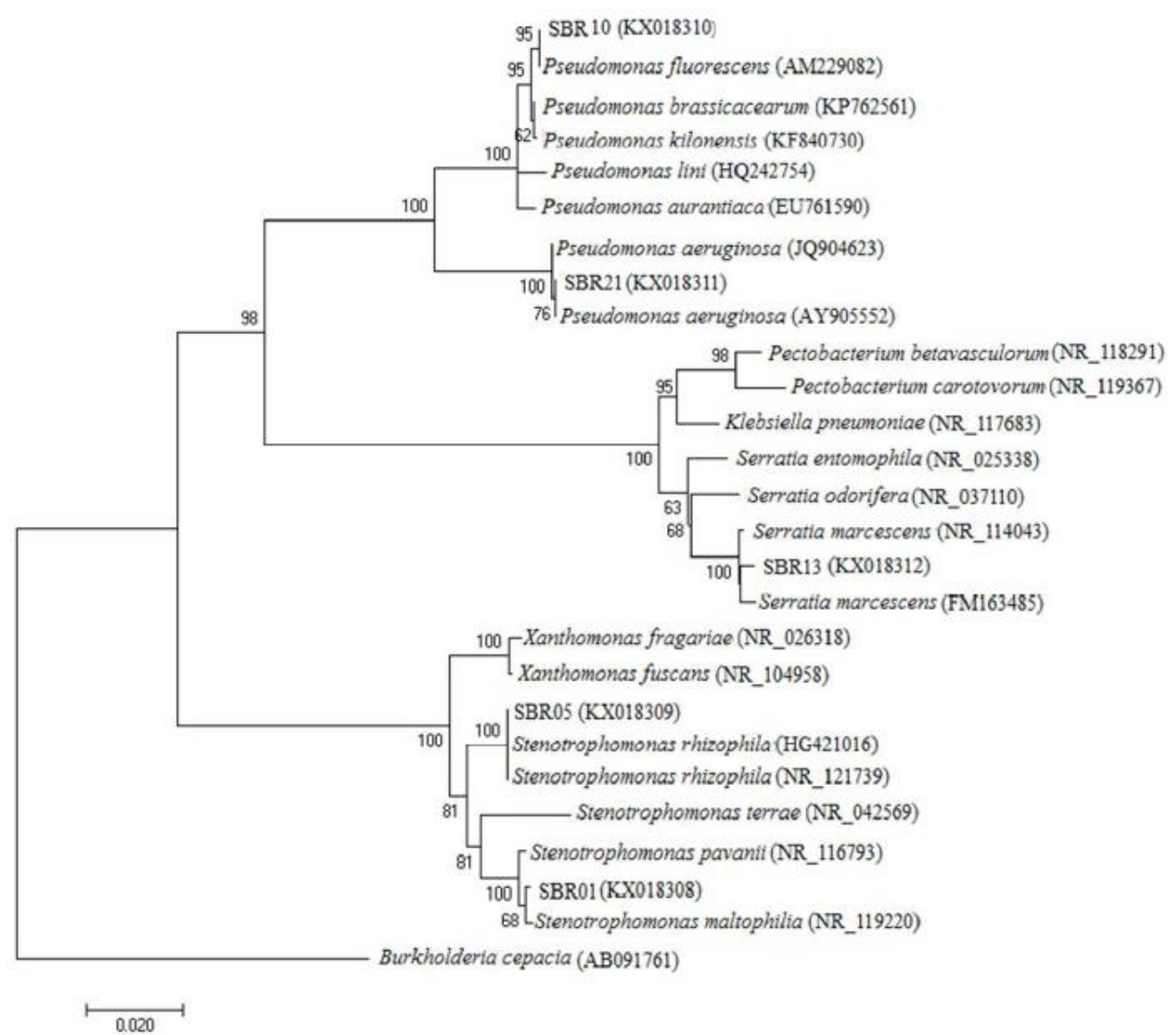

Figure 4- Phylogenetic analysis of SBR01, SBR05, SBR10, SBR13, SBR21 and related species by the Neighbor Joining method based on 16S rRNA gene sequences. The GenBank accession number for each microorganism used in the analysis is shown in parentheses after the species name. Bootstrap values (expressed as percentage of 100 replicons) are shown at the nodes.

Table 2. SDS-PAGE fingerprint types and number of isolates in the rhizosphere of sugar beet.

Identification

Fingerprint

Number of isolates

types $^{\mathrm{a}}$

Major fingerprint types

Stenotrophomonas maltophilia

SBR01

31

Pseudomonas fluorescens

SBR10

27

Stenotrophomonas rhizophila

SBR05

Pseudomonas aeruginosa

SBR21

Serratia marcescens

SBR13 
Minor fingerprint types

Gram-negative

Flavobacterium spp

6

15

Erwinia spp

7

15

Acetobacter spp

5

14

Agrobacterium spp

5

12

Enterobacter spp

4

10

Aeromonas spp

5

\section{9}

Gram-positive

\begin{tabular}{lll} 
Bacillus spp & 6 & 14 \\
\hline Total & 43 & 217 \\
\hline
\end{tabular}

${ }^{\mathrm{a}}$ For the minor fingerprint types, the total number of different fingerprint types is given.

Table 3. Relative frequency of the major fingerprint types according to the sampling regions.

\begin{tabular}{llllllll}
\hline $\begin{array}{l}\text { Major } \\
\text { fingerprints }\end{array}$ & Kermanshah & Mahidasht & $\begin{array}{l}\text { Eslamabad- } \\
\text { e Gharb }\end{array}$ & Hamedan & Malayer & $\begin{array}{l}\text { Shahin } \\
\text { Dezh }\end{array}$ & Miandoab \\
\hline SBR01 & 7 & 4 & 5 & 5 & 4 & 3 & 3 \\
SBR05 & 5 & 4 & 3 & 0 & 6 & 2 & 5 \\
SBR10 & 7 & 5 & 4 & 3 & 3 & 0 & 5 \\
SBR13 & 0 & 3 & 4 & 4 & 5 & 3 & 3 \\
SBR21 & 1 & 4 & 4 & 3 & 7 & 4 & 0 \\
\hline Total & 20 & 20 & 20 & 15 & 25 & 12 & 16 \\
\hline
\end{tabular}

Table 4. Biochemical and molecular analysis of the major fingerprint types.

\begin{tabular}{|c|c|c|c|c|c|}
\hline $\begin{array}{l}\text { Biochemical } \\
\text { tests }\end{array}$ & SBR01 & SBR05 & SBR10 & SBR13 & SBR21 \\
\hline Gram reaction & - & - & - & - & - \\
\hline Motility & + & + & + & + & + \\
\hline $\begin{array}{c}\text { Growth in at } \\
4^{\circ} \mathrm{C}\end{array}$ & - & + & + & - & - \\
\hline $\begin{array}{c}\text { Growth in at } \\
37^{\circ} \mathrm{C}\end{array}$ & + & + & - & - & + \\
\hline $\begin{array}{l}\text { Growth on } \\
7 \% \mathrm{NaCl}\end{array}$ & - & + & + & + & - \\
\hline $\begin{array}{l}\text { Production of } \\
\text { fluorescent } \\
\text { pigment }\end{array}$ & - & - & + & - & - \\
\hline Catalase & + & + & + & + & + \\
\hline Oxidase & - & - & + & - & + \\
\hline Urease & - & - & + & - & + \\
\hline Lecithinase & + & - & + & nd & nd \\
\hline $\begin{array}{l}\text { Nitrate } \\
\text { reduction }\end{array}$ & + & + & - & + & - \\
\hline Methionine & + & + & - & nd & - \\
\hline
\end{tabular}


Rhizosphere bacterial of the sugar beet

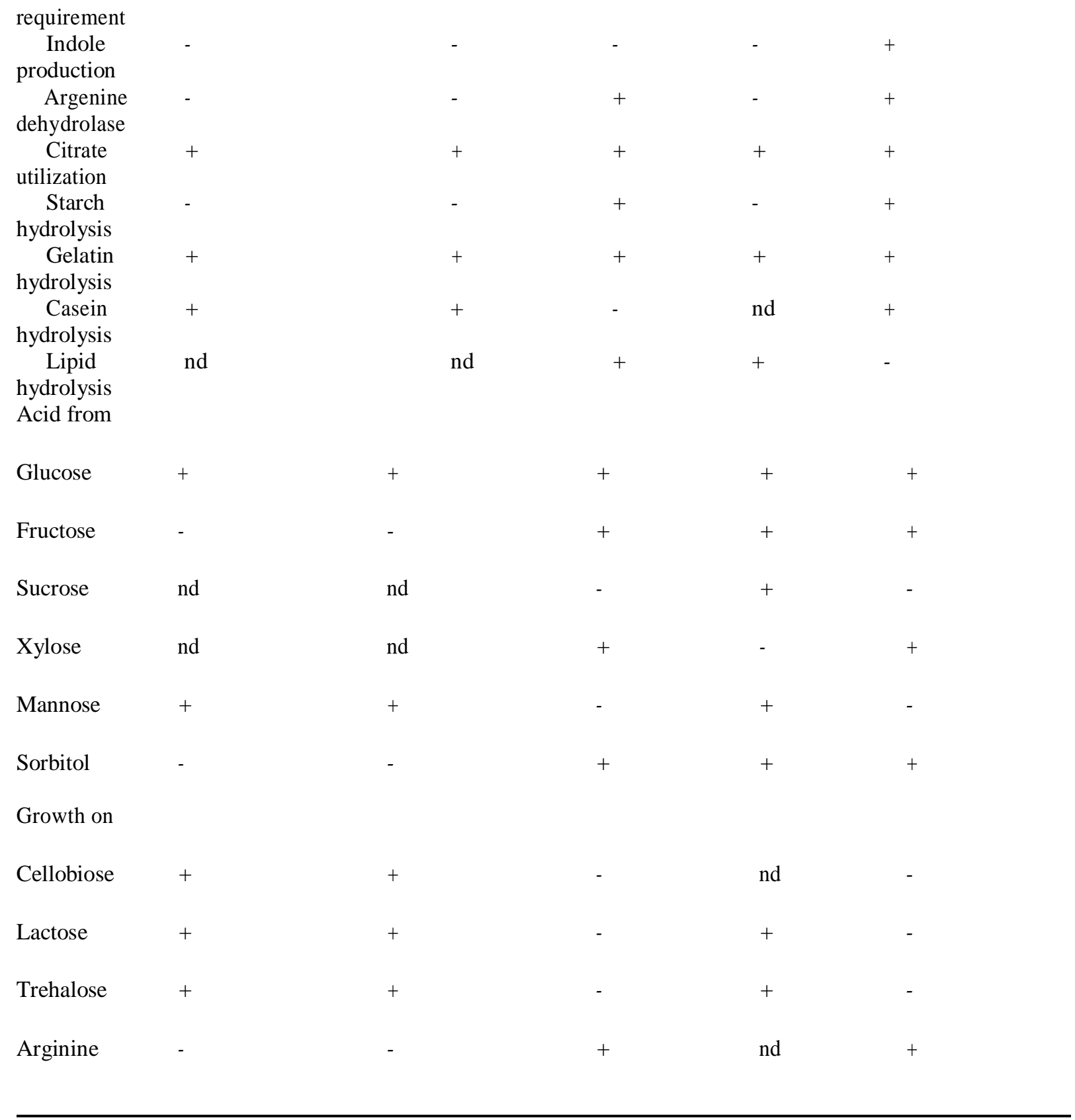

Molecular analysis

\begin{tabular}{|c|c|c|c|c|c|}
\hline Identification & Stenotrophomonas & Stenotrophomonas & Pseudomonas & Serratia & Pseudomonas \\
\hline based on $16 \mathrm{~s}$ & $\begin{array}{l}\text { Maltophilia } \\
\text { rNA gene } \\
\text { sequencing }\end{array}$ & Rhizophila & Fluorescens & Marcescens & Aeruginosa \\
\hline
\end{tabular}

+ , representing the positive reaction and - , shows the negative reaction. nd: not done. The experiment was repeated twice for each representative isolate.

\section{DISCUSSION}


The present study was designed to describe how to use electrophoretic protein patterns to report the rhizosphere bacteria populations. In this investigation, the rhizosphere bacteria were isolated from of the major sugar beet growing regions in the west of Iran. In the rhizosphere, bacteria are the most abundant microorganisms. Rhizobacteria are rhizosphere competent bacteria that aggressively colonize plant roots; they are able to multiply and colonize all the ecological niches found on the roots at all stages of plant growth, in the presence of a competing microflora (24). Among the factors that determine the structure of microbial communities in the rhizosphere, the plant plays a major role (25) by releasing organic compounds to soil, a process called rhizodeposition or exudation (26). The effect of specific compounds released by the plant root on the selection of the microbiota of the rhizosphere was first demonstrated by Gunner et al (1966) (27). Specific bacterial communities have been observed in the rhizosphere of field-grown strawberry

(Fragaria ananassa Duch.), oil-seed rape (Brassica napus L.), and potato (Solanum tuberosum L.) (28). Our finding revealed that five species were found to be dominant in the rhizosphere of sugar beet. It can, therefore, be assumed that these types of bacteria are more adapted to sugar beet rhizospheres. These bacteria are probably able to respond rapidly to the energy released by roots of sugar beet. It is possible to hypothesize that these organisms are the resident of sugar beet roots in the west of Iran because they can live and multiply in that specific ecosystem. Totally, a few gram-positive isolates were found. The results of this study show that the majority of the isolates were gram negative, which indicates their successful root-colonization capacities. These results further support the idea that the rhizosphere of many plants provides a favorable environment for gram-negative bacteria most of which are motile. Under these circumstances, these gramnegative bacteria are stimulated by rhizodeposition whereas gram-positive bacteria are inhibited (29). For studies on the rhizosphere comprising hundreds of bacteria, it was decided that the best method to adopt for this investigation was to use a sodium dodecyl sulfate-polyacrylamide gel electrophoresis (SDS-PAGE) fingerprint technique to assess the rhizobacterial populations of sugar beet. Electrophoretic separation of cellular proteins has been used for classification, identification and typing of diverse bacterial taxa (30). As cellular protein profiles provide second-level information for a cell, characterization based on electrophoretic protein patterns of SDS-PAGE correlated closely with the genotyping results that suggest that it could be an effective method for rapid bacterial classification(31). By comparing the protein patterns of all isolates from each plant, we could determine an average rhizobacterial composition of sugar beet. Furthermore, SDS - PAGE could be an inexpensive and fast procedure allowing the rational use of microorganism collections.

Two of the major fingerprint types SBR07 and SBS15 were identified as $S$. maltophilia and S. rhizophila.

These two species are typical plant-associated microorganisms. Their main reservoir is the rhizosphere of plants $(32,33)$. Serratia sp. are associated with soil (34) and also $S$. marcescens has been reported from the rhizosphere $(35,36)$. The results of this investigation showed that two of the major occurring bacteria belonged to Pseudomonas genus. A possible explanation for this might be attributed to the diversity and the ecologically importance of this group of bacteria which is found in huge numbers in all the major natural environments and also in associations with plants. Obviously, this widespread distribution suggests a significant degree of physiological and genetic adaptability (37). The results of this study seem to be consistent with other research which found that P. fluorescens and Xanthomonas maltophilia were the major bacteria in the rhizosphere of young sugar beet plants (38). In this study, whole $16 S$ rRNA gene sequencing has been used for identification of representative strains isolated from rhizosphere. In most cases, sequencing 
the entire 1,500-bp region is necessary to distinguish between particular taxa or strains (37). Identifying and characterizing the rhizosphere bacteria of crops help to enable the manipulation of the beneficial bacteria to improve crop yield, how this might be applied to agriculture and improve the understanding of co-operative activities among rhizosphere bacteria. Knowledge of the native bacterial population, their characterization, and identification is fundamental for understanding the distribution and diversity of indigenous bacteria in the rhizosphere of specific crops (38). With increasing concern about the-chemical-fertilizers-based agricultural practices, it is essential to investigate for region-specific microbial strains which can be used as a growthpromoting inoculum to attain desired crop production (39). In general, these native bacteria were adapted to the rhizosphere and are potentially useful as plant growth promoting bacteria, thus broadening the spectrum of PGPR available for field application. These study findings enhance our understanding of a resident population of microorganisms in the rhizosphere of sugar beet roots and will serve as a base for future studies.

\section{CONCLUSIONS}

Summarizing, this study has shown that PAGE provided an efficient screening of a large number of isolates and provides a framework for the exploration of the general picture of sugar beet rhizosphere microflora in the west and north west of Iran by means of the frequently occurring fingerprint types (electrotype). In future investigations, functional analyzes of these sugar beet rhizosphere-associated bacteria should be conducted in order to clarify their ecological roles in a rhizosphere.

\section{REFERENCES}

1. Sorensen J. The rhizosphere as a habitat for soil microorganisms, In: Van Elsas, J.D., Trevors J. T and Wellington E. M. H. (eds.) Modern Soil Microbiology. Marcel Dekker, New York/ Basel/Hongkong. 1997. pp. 21-45.

2. Whipps J. Microbial interactions and biocontrol in the rhizosphere. J Exp Bot. 2001; 52: 487-511.

3. Lynch JM. Introduction: some consequences of microbial rhizosphere competence for plant and soil. In: Lynch JM (ed.) The Rhizosphere. John Wiley \& Sons, Ltd. Chichester, UK. 1990. pp. 1-10.

4. Kloepper JW, Schroth MN. Plant growth promoting rhizobacteria on radishes. In Proceedings of the 4th International Conference on Plant Pathogenic Bacteria, ed. Station de Pathologie Vegetal et. Phytobacteriologie. 1978; 2: 879- 882. Angers, France.

5. Thakuria D, Talukdar NC, Goswami C, Hazarika S, Boro RC, Khan MR. Characterization and screening of bacteria from rhizosphere of rice grown in acidic soils of Assam. Curr Sci. 2004; 86: 978-985.

6. Khalid A, Arshad M, Zahir ZA. Screening plant growth-promoting rhizobacteria for improving growth and yield of wheat. J Appl Microbiol. 2004; 96: 473-480.

7. Suslow TV, Schroth MN. Rhizobacteria of sugar beets: effects of seed application and root colonization on yield. Phytopathol. 1982; 72:199-206

8. Bloemberg GV, Lugtenberg BJ. Molecular basis of plant growth promotion and biocontrol by rhizobacteria. Curr Opin Plant Biol. 2001; 4: 343-350.

9. Amaresan N, Jayakumar V, Kumar K, Thajuddin N. Isolation and characterization of plant growth promoting bacteria and their effect on tomato (Lycopersicon esculentum) and chili (Capsicum annuum) seedling growth. Ann Microbiol. 2011; 62: 805-810.

10. Chahboune R, Barrijal S, Moreno S, Bedmar EJ. Characterization of Bradyrhizobium species isolated from root nodules of Cytisus villosus grown in Morocco. Syst Appl Microbiol. 2011; 34: 440-445 
11. Kirk JL, Beaudette LA, Hart M, Moutoglis P, Klironomos JN, Lee H, Trevors JT. Methods of studying soil microbial diversity. J Microbiol Methods. 2004; 58: 169- 188.

12. Grayston SJ, Wang SQ, Campbell CD, Edwards AC. Selective influence of plant species on microbial diversity in the rhizosphere. Soil Biol Biochem. 1998; 30: 369-378.

13. Jarvis AW, Wolff JM. Grouping of lactic streptococci by gel electrophoresis of soluble extracts. Appl Environ Microbiol. 1979; 37: 391-398.

14. Ohya T, Kubo M, Watase H. Electrophoretic protein patterns in Campylobacter species with special reference to Campylobacter mucosalis and Campylobacter hyointestinalis. Jpn J Vet Sci. 1988; 50: 692-698.

15. Chaparro JM, Badri DV, Bakker MG, Sugiyama A, Manter DK, Vivanco JM. Root exudation of phytochemicalsin Arabidopsis follows specific patterns that are developmentally programmed and correlate with soil microbial functions. PLOSONE. 2013; 8: e55731.

16. Berg G, Smalla K. Plant species and soil type cooperatively shape the structure and function of microbial communities intherhizosphere. FEMS Microbiol Ecol. 2009; 68: 113.

17. Bulgarelli D, Rott M, Schlaeppi K, Themaat EVLV, Ahmadinejad N, Assenza F, et al. Revealing structure and assembly cues for Arabidopsis root-inhabiting bacterial microbiota. Nature. 2012; 488: 91-95.

18. Engelhard M, Hurek T, Reinhold-Hurek B. Preferential occurrence of diazotrophic endophytes, Azoarcus spp., in wild rice species and land races of Oryza sativa in comparison with modern races. Environ Microbiol. 2000; 2:131-141.

19. Dristig MCG, Dianese JC. Characterisation of Pseudomonas solanacearum biovars based on membrane protein patterns. Phytopathol. 1990; 80: 641-646.

20. Laemmli UK. Cleavage of structural proteins during the assembly of the head of bacteriophage T4. Nature. $1970 ; 227: 680-685$.

21. Brenner DJ, Krieg NR, Staley JT, Garrity GM. Bergey's Manual of Systematic Bacteriology, 2nd ed., vol. 2, Springer-Verlag, New York, NY, 2005.1106pp.

22. Weisburg WG, Barns SM, Pelletier DA, Lane DJ. 16S Ribosomal DNA Amplification for Phylogenetic Study. J Bacteriol. 1991; 173: 697-703.

26. Lambert B, Leyns F, Van Rooyen L, Gossele F, Papon Y, Swings, J. Rhizobacteria of maize and their antifungal activities. Appl Environ Microbiol.1987; 53: 1866-1871.

24. Antoun $\mathrm{H}$ and Kloepper JW. Plant growth-promoting rhizobacteria (PGPR), in: Encyclopedia of Genetics, Brenner, S. and Miller, JH, eds., Academic Press, N.Y. 2001. pp. 1477-1480.

25. Marilley L, Vogt G, Blanc M, Aragno M. Bacterial diversity in the bulk soil and rhizosphere fractions of Lolium perenne and Trifolium repens as revealed by PCR restriction analysis of $16 S$ rDNA. Plant Soil. 1998; 198: 219- 224.

23. Whipps JM, Lynch JM. Energy losses by the plant in rhizodeposition. Annu Proc Phytochem Soc Eur. 1985; 26: 59- 71.

27. Gunner HB, Zuckerman BM, Walker RW, Miller CW, Deubert KH, Lonley RE. The distribution and persistence of diazinon applied to plant and soil and its influence on rhizosphere and soil microflora. Plant Soil. 1966; 25:249- 264.

28. Ciccazzo S, Esposito A, Rolli E, Zerbe S, Daffonchio D, Brusetti L. Different pioneer plant species select specific rhizosphere bacterial communities in a high mountain environment. Springerplus. 2014; 3: 391.

29. Johansen A, Olsson S. Using phospholipid fatty acid technique to study short-term effects of the biological control agent Pseudomonas fluorescens DR54 on the microbial microbiota in barley rhizosphere. Microb Ecol. 2005; 49: 272- 281.

30. Garber ED, Rippon JW. Proteins and enzymes as taxonomic tools. Adv Appl Microbiol. 1968; 10:137-54.

31. Vauterin L, Vantomme R, Pot B, Hoste B, Swings J, Kersters K. Taxonomic analysis of Xhantomonas campestris pv. begonidae and $X$. campestris pv. pelargonii by means of phythopathological, phenotypic, protein electrophoretic and DNA hybridization methods. Syst Appl Bacteriol. 1990; 1: 166-167.

32. Juhnke ME, Des Jardin E. Selective medium for isolation of Xanthomonas maltophilia from soil and rhizosphere Environments. Appl Environ Microbiol. 1989; 55: 747-750. 
Rhizosphere bacterial of the sugar beet

33. Berg G, Marten P, Ballin G. Stenotrophomonas maltophilia in the rhizosphere of oilseed rape-occurrence, characterization and interaction with phytopathogenic fungi. Microbiol Res. 1996; 151: 19-27.

34. Ashelford KE, Fry JC, Bailey MJ, Day MJ. Characterization of Serratia isolates from soil, ecological implications and transfer of Serratia proteamaculans subsp quinovora Grimont et al 1983 to Serratia quinivorans corrig. Sp nov. Int J of Syst Evol Microbiol. 2002; 52: 2281- 2289.

35. Berg G, Fritze A, Roskot N, Smalla K. Evaluation of potential biocontrol rhizobacteria, from different host plants of Verticillium dahliae Kleb. J Appl Microbiol. 2001; 91: 963971.

36. Hameeda B, Reddy YH, Rupela OP, Kumar GN, Reddy, G. Effect of carbon substrates on rock phosphate solubilization by bacteria from composts and macrofauna. Curr Microbiol. 2006; 53: 298-302.

37. Spiers AJ, Buckling A, Rainey PB. The causes of Pseudomonas diversity. Microbiol. 2002; 146: 2345-2350.

38. Lambert B, Meire P, Joos H, Lens P, Swings J. Fast-growing, aerobic, heterotrophic bacteria from the rhizosphere of young sugar beet plants. Appl Environ Microbiol. 1990; 56: 3375-81.

37. Sacchi CT, Whitney AM, Reeves, MW, Mayer LW, Popovic TJ. Clin Sequence diversity of Neisseria meningitides $16 \mathrm{~S}$ rRNA genes and use of $16 \mathrm{~S}$ rRNA gene sequencing as a molecular subtyping tool. Microbiol. 2002; 40: 4520- 7.

38. Keating JD, Beck L, Materon A, Yurtsever N, Karuc K, Altuntas S. The role of D. P rhizobial diversity in legume crop productivity in the west Asian Highlands. Exp Agric. 1995; 31: 473-483.

39. Deepa CK, Dastager SG, Pandey A. Isolation and characterization of plant growth promoting bacteria from nonrhizospheric soil and their effect on cowpea (Vigna unguiculata (L.) Walp.) seedling growth. World J Microbiol Biotechnol. 2010; 26:12331240 . 